\title{
Efficacy and safety of pancreatic enzyme replacement therapy on exocrine pancreatic insufficiency: a meta-analysis
}

\author{
Can Gan ${ }^{1,2, *}$, Yan-Hua Chen ${ }^{1,2, *}$, Ling Liu ${ }^{1,2}$, Jin-Hang Gao ${ }^{1}$, Huan Tong ${ }^{1,2}$, Cheng- \\ Wei Tang ${ }^{1,2}$ and Rui Liu ${ }^{1}$ \\ ${ }^{1}$ Division of Peptides Related with Human Diseases, State Key Laboratory of Biotherapy, West China Hospital, Sichuan University, \\ Chengdu, China \\ ${ }^{2}$ Department of Gastroenterology, West China Hospital, Sichuan University, Chengdu, China \\ *These authors contributed equally to this work and should be considered as co-first authors
}

Correspondence to: Cheng-Wei Tang, email: shcqcdmed@163.com

Rui Liu, email: Irui60@163.com

Keywords: pancreatic enzyme replacement therapy, exocrine pancreatic insufficiency, efficacy, safety, standardization

Received: July 12, 2017

Accepted: September 21, 2017

Published: October 07, 2017

Copyright: Gan et al. This is an open-access article distributed under the terms of the Creative Commons Attribution License 3.0 (CC BY

3.0), which permits unrestricted use, distribution, and reproduction in any medium, provided the original author and source are credited.

\section{ABSTRACT}

Background: Pancreatic enzyme replacement therapy (PERT) is widely applied to patients with exocrine pancreatic insufficiency (EPI), but its effect and safety has not been quantified. Therefore we performed a meta-analysis to determine the efficacy and tolerance of PERT on patients with EPI.

Materials and Methods: PubMed, Medline, Cochrane library database, Evidencebased medicine/clinical trials published before December 2016 were searched by two independent reviewers to identify prospective randomized controlled trials (RCTs).

Results: Seven RCTs, randomizing a total of 282 patients, were filtrated and assessed qualitatively (Jadad score). PERT increased CFA (WMD: 26.56, 20.35 to $32.76, \mathrm{I}^{2}=79.6 \%, P<0.001$ ) compared with baseline, and CFA (WMD: 17.97, 12.61 to $23.34, \mathrm{I}^{2}=76.7 \%, P<0.001$ ) vs. placebo. Meanwhile, CNA, SFE, SNE and SW were significantly improved in PERT compared with baseline and placebo, with no statistical differences in adverse events. Subgroup analysis indicated that standard forms of PERT displayed more effectiveness with significantly decreased heterogeneity, and large sample size also reduced the heterogeneity to some degree.

Conclusions: PERT is demonstrated to be effective and tolerable in patients with EPI, especially using standard administration of PERT. Larger and higher quality studies on EPI are demanded to long-term effect of standard PERT treatment.

\section{INTRODUCTION}

Exocrine pancreatic insufficiency (EPI), characterized as decreased synthesis or secretion of pancreatic enzymes and bicarbonate, occurs with parenchyma dysfunction or reduction or the ductal obstruction due to preexisting pancreatic diseases, leading to the maldigestion of food and subsequently malabsorption of nutrients $[1,2]$. The common clinical symptoms remain recurrent abdominal pain, flatulence and weight loss, accompanied with typical steatorrhea in the case of pancreas lipase output decrease to < $10 \%$ of normal [3]. The diagnosis of EPI can be made on the basis of clinical manifestation besides auxiliary examinations: direct and indirect pancreatic function tests. The former containing endoscopic function testing, secretin-magnetic resonance pancreatography and secretin-endoscopic ultrasonography is sensitive but expensive and inaccessibility, the latter testing the contents of undigested food and stool is widely used for its convenience and facility [4-6].

Moreover, continuous malabsorption has a longterm negative effect on multiple systems, for example nyctalopia, cerebellar ataxia, increased prothrombin time and osteoporosis, increasing morbidity and mortality related to malnutrition $[7,8]$. While the main causes of EPI remain chronic pancreatitis $(\mathrm{CP})$, cystic fibrosis $(\mathrm{CF})$ and pancreatic surgery (PS) [9]. 
Chronic pancreatitis, a chronic progressive inflammatory syndrome with irreversible damage on pancreatic parenchyma, mainly results from alcohol exposure, smoking, hyperlipidemia, genetic mutation and autoimmune diseases, [10] often manifesting the clinical signs of EPI. Cystic fibrosis, common life-shortening genetic disease in white individuals, affects epithelial secretory tissues and results in pancreatic and pulmonary dysfunction, with symptoms of EPI, such as poor weight, growth restriction and gastrointestinal symptoms [11]. Pancreatic surgery including partial and total resection, is usually used in the administration of pancreatic neoplasm or chronic pancreatitis. But it is still unclear whether postoperative pancreatic dysfunction derives from the extent of resection or the underlying pancreatic disease or the combination of both [1].

Pancreatic enzyme replacement treatment (PERT), a mixture of the digestive enzymes amylase, lipase, and protease, are widely utilized in management of EPI as an exogenous supplement whatever etiology for its efficacy, safety and toleration. PERT contains enteric-coated and non-enteric-coated capsules minimicrospheres, microspheres and tablets with various doses. As oral administration of pancreatic enzymes is vulnerable to gastric juice, enteric-coated capsules can protect the contents when transit through the stomach without aciddegradation to effectively release in duodenum with chyme. Minimicrospheres and microspheres, each with only a few millimeters in diameter, disperse more evenly and rapidly in chyme compared with conventional tablets [12].

However, therapeutic effects of PERT still remain equivocal. Yaghoobi M [13] conducted a systematic review that PERT failure to relieve abdominal pain in patients with CP. Whereas PERT were testified to be safe and effective in a systematic review and meta-analysis [14]. Another systematic reviews concluded that PERT cannot normalize the fat malabsorption, $[15,16]$ or the impacts on $\mathrm{CP}$ or $\mathrm{CF}$ are incomplete and inconsistent $[17,18]$. Hence, to better understand the effect of PERT for EPI, we synthesized published RCTs via a metaanalysis, to quantitatively evaluate the coefficient of fat absorption (CFA), coefficient of nitrogen absorption (CNA), stool fat excretion (SFE), stool nitrogen excretion (SNE), stool weight (SW), abdominal pain and adverse events by comparing PERT with placebo.

\section{RESULTS}

A total of 228 studies were identified according to the searching strategy about pancreatic enzyme replacement therapy and exocrine pancreatic insufficiency. And seven RCTs met the criteria, with 282 patients (149 in the PERT group and 133 in the placebo group) randomized. Figure 1 depicts the PRISMA flow diagram.

\section{Characteristics and quality of included studies}

The basic characteristics of included studies are shown in Table 1. Of the seven RCTs, four were from multicenter [19-22] and the rest from single, [23-25] while six were parallel design $[19-22,24,25]$ and one cross-over design [23]. Three studies were in Europe, [22-24] one in the USA, [19] one in India, [21] one in South Africa [25] and one in the USA and Europe [20]. The definition of EPI caused by chronic pancreatitis or pancreatic surgery are presented: CFA $<80 \%,[21,22]$ $\mathrm{CFA}<80 \%$ or SFE $>10 \mathrm{~g} / \mathrm{d}$, [19] SFE $>15 \mathrm{~g} / \mathrm{d}$, [20] SFE $\geq 10 \mathrm{~g} / \mathrm{d},[24,25] \mathrm{SFE}>7 \mathrm{~g} / \mathrm{d}$ [23]. Five studies included post pancreatic surgery patients [20-22, 24, 25]. And quality of each study was assessed by Jadad score in Table 2 (six studies high quality, [19-24] one low quality [25]).

Patients enrolled first had to finish a run-in phase or wash-out phase to filter eligible participants before double-blind treatment phase. And stool collection was performed to detect the fat and nitrogen contents and stool weight. Intervention was given with placebo or PERT randomly, which contained main four types in entericcoated microtablet or microspheres or minimicrospheres: Creon $^{\circledR}$ in four studies, [19-22] Pancrease ${ }^{\circledR}$ in one, [23] Panzytrat ${ }^{\circledR}[24]$ in one and a non-informed type in one study. [25] Creon ${ }^{\circledR}$ and Pancrease ${ }^{\circledR}$ have been approved by the US Food and Drug Administration, acknowledged to be standard [26]. Daily fat intake was recorded during both periods for calculating the fat absorption. Mean change of CFA increased in PERT compared with placebo statistical significantly in five studies. Adverse events incidences measured in five studies were developed in both PERT and placebo group. (Table 3).

\section{Meta-analysis of main outcomes}

Figure 2 shows the results of PERT group versus baseline. Overall results revealed that CFA increased in PERT versus baseline (WMD: 26.56, 20.35 to 32.76, $P<0.001)$ despite considerable heterogeneity $\left(\mathrm{I}^{2}=79.6 \%\right)$, enhanced CNA in PERT versus baseline in four studies $(P=0.004)$, decreased SFE in six studies $(P<0.001)$, decreased SNE in four studies $(P=0.080)$, reduced SW in four studies $(P=0.018)$.

Figure 3 presents the results of PERT versus placebo group. The pooled results declared enhanced CFA in PERT vs. placebo (WMD: $17.97,12.61$ to $23.34, P<0.001$ ) in spite of obvious heterogeneity $\left(\mathrm{I}^{2}=76.7 \%\right)$, increased CNA in three studies $(P=0.063)$, decreased SFE in seven studies $(P<0.001)$, depressed SNE in four studies $(P=0.102)$, depressed SW in five studies $(P=0.001)$. Treatment-emergent adverse events manifesting abdominal pain/discomfort and flatulence during the treatment phase among PERT and placebo group did not reach significant differences (RR: 1.17, 0.76 to 1.81 , $P=0.466$ ) with $\mathrm{I}^{2}=0.0 \%$ in five studies. 


\section{Subgroup analyses}

Due to high heterogeneity, we performed random effect analysis and subgroup analysis to explore the potential causes. (Table 4).

\section{Standard PERT forms versus non-standard PERT forms}

Five studies using standard forms of PERT as a group was compared with non-standard group. CFA was improved more in standard forms with a statistically significant decreased heterogeneity ( $\mathrm{I}^{2}$ : from $76.7 \%$ to $41.1 \%, P=0.15$ ).

\section{Small sample $(\leq \mathbf{5 0})$ versus large sample $(>\mathbf{5 0})$}

Three studies were allotted to large numbers of patients, and four assigned to small. CFA was improved in large numbers with a decreased heterogeneity. ( $\mathrm{I}^{2}$ : from $76.7 \%$ to $66.2 \%, P=0.05)$.

\section{Sensitivity analyses}

\section{Each trial's contribution to the combined effect}

The remained therapeutic effect was still significant with high heterogeneity after excluding a study in turn. (Figure 4) Effect of the methodological quality of studies. The effect remained unchanged and robust with decreased heterogeneity after excluding a low-quality study ( $\mathrm{I}^{2}$ : from $76.7 \%$ to $67.0 \%, P=0.01$ ).

\section{DISCUSSION}

In the meta-analysis we combined primary and secondary evidences from seven RCTs involving 282 patients with chronic pancreatitis or post pancreatic surgery, to evaluate the efficacy and safety of PERT for EPI. And we made several key observations.

First, PERT effectively improved CFA, CNA, SFE, SNE and SW in contrast to baseline and placebo. Second, adverse events between PERT and placebo group had no significant differences. These events mainly manifest mild to moderate gastrointestinal syndromes such as abdominal pain and flatulence, which may also associate with the underlying pancreatic diseases. In addition, standard forms of PERT and sample size contributed to the heterogeneity detected by subgroup analysis. Studies of standard PERT treatment performed higher beneficial effects on EPI without safety concerns with significantly decreased heterogeneity, which provided more stable and persuasive evidence. After grouping large sample sizes, the heterogeneity decreased though not significantly, it proved more steady and convincing results, which may enlighten larger size RCTs on the therapeutic effect of PERT.

Besides above, the pathogeny of exocrine pancreatic insufficiency might contribute to the heterogeneity. Various types and severities of diseases response and tolerate differently to the interventions. Alcoholic, idiopathic, obstructive or hyperlipidemic sources might form the basis

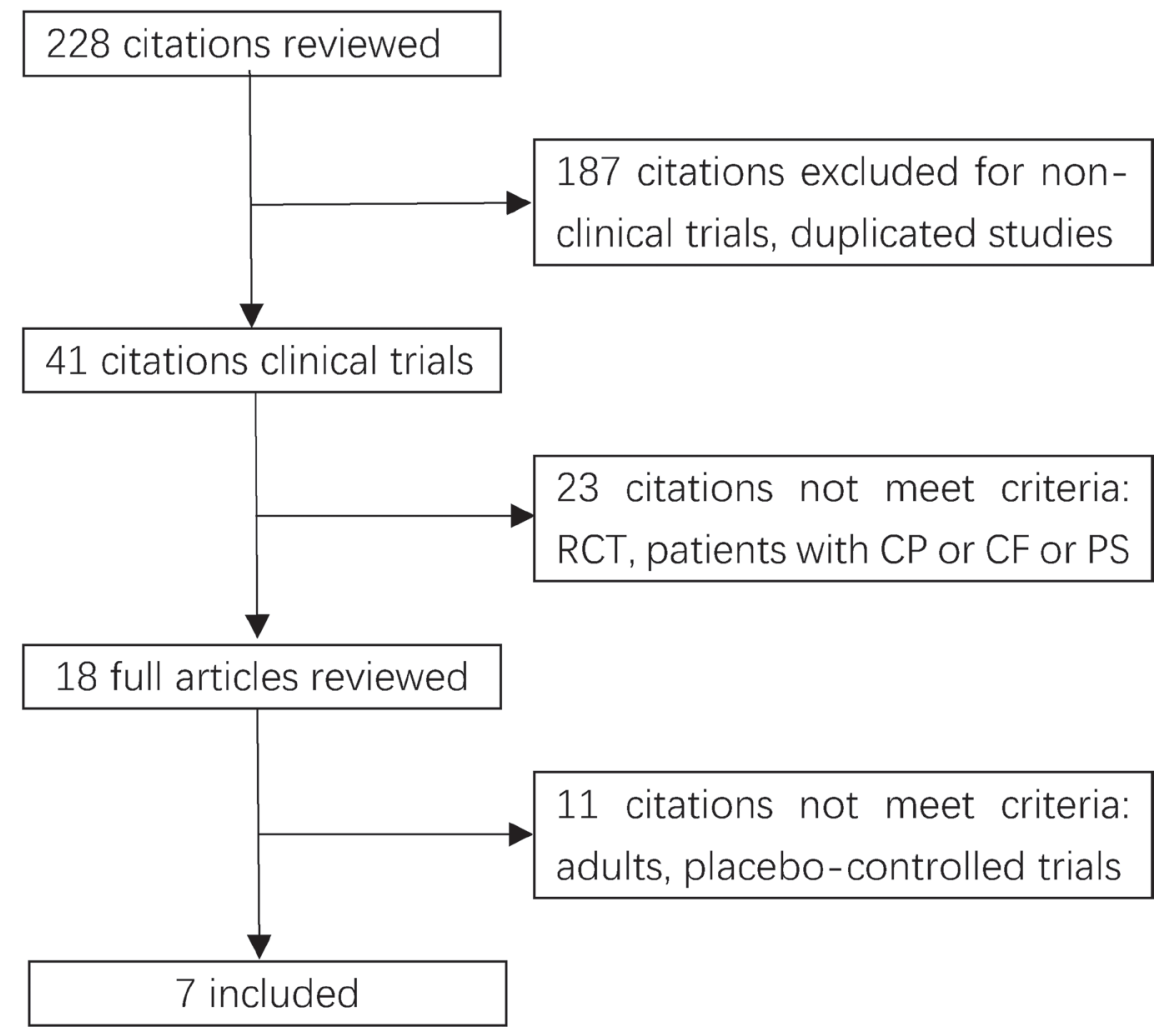

Figure 1: Flow chart of study selection. RCT: randomized controlled trials. CP: chronic pancreatitis. PS: pancreatic surgery 
Table 1: Basic characteristics of included studies

\begin{tabular}{|c|c|c|c|c|c|c|c|c|}
\hline Author, Year & Country & Duration & Study design & Inclusion criteria & Etiology & $\begin{array}{c}\text { No of } \\
\text { post-ps }\end{array}$ & Age & $\begin{array}{c}\text { Patients } \\
\text { randomized } \\
\text { (male/female) }\end{array}$ \\
\hline Halgreen, 1986 & Denmark & NR & $\begin{array}{l}\text { Single, randomized, } \\
\text { double-blind, placebo- } \\
\text { controlled, cross-over }\end{array}$ & $\begin{array}{c}\text { Adults, } \mathrm{CP} \text {, reduced EPF, with a } \\
\text { meal-stimulated duodenal lipase } \\
\text { concentration of less than } 50 \mathrm{kU} / \mathrm{L} \\
\text { and a SFE }>7 \mathrm{~g} / \text { day. }\end{array}$ & $\begin{array}{l}\text { A4; I3 } \\
\text { O3; H1 }\end{array}$ & NR & $29-59(51)$ & $11(6 / 5)$ \\
\hline Paris, 1993 & France & $\begin{array}{c}\text { June } 1986 \text { to } \\
\text { June } 1987\end{array}$ & $\begin{array}{l}\text { Single, randomized, } \\
\text { double-blind, placebo- } \\
\text { controlled, parallel }\end{array}$ & $\begin{array}{l}\text { Radiologically or perioperatively } \\
\text { confirmed CAP, Previous } \\
\text { steatorrhea } \geq 10 \mathrm{~g} / 24 \mathrm{~h}) .\end{array}$ & A 60 & $\begin{array}{l}\mathrm{R}, \text { not } \\
\text { clearly }\end{array}$ & 47 & $41(35 / 6)$ \\
\hline O'Keefe, 2001 & South Africa & NR & $\begin{array}{l}\text { Single, randomized, } \\
\text { placebo-controlled, } \\
\text { parallel }\end{array}$ & $\begin{array}{l}\geq 18 \mathrm{y} \text {, evidence of CP }(\mathrm{CT}, \mathrm{US}, \\
\text { ERCP et al) and EPI(SFE }>10 \mathrm{~g} / \\
\text { day in run-in phase })\end{array}$ & A $27 ;$ I 2 & 9 & $\begin{array}{l}49.1 \pm 1.8 \\
\text { years vs. } 57.8 \\
\quad \pm 2.1\end{array}$ & $29(28 / 1)$ \\
\hline Safdi, 2006 & USA & NR & $\begin{array}{l}\text { Multicenter, randomized, } \\
\text { double-blind, placebo- } \\
\text { controlled parallel }\end{array}$ & $\begin{array}{c}\geq 18 \mathrm{y}, \text { documented CP, EPI(CFA } \\
<80 \% \text { and } / \text { or } \mathrm{SFE}>10 \mathrm{~g} / \text { day in } \\
\text { run-in phase })\end{array}$ & NR & NR & $\begin{array}{l}\text { Placebo } 51 \\
\text { PERT } 51.9\end{array}$ & $27(9 / 18)$ \\
\hline Whitcomb, 2010 & $\begin{array}{l}\text { USA\& } \\
\text { Europe }\end{array}$ & $\begin{array}{c}\text { April } 2007 \\
\text { to August } \\
2008\end{array}$ & $\begin{array}{l}\text { Multicenter, randomized, } \\
\text { double-blind, placebo- } \\
\text { controlled parallel }\end{array}$ & $\begin{array}{l}\geq 18 \mathrm{y}, \text { EPI (stool elastase }<100 \mu \\
\mathrm{g} / \mathrm{g}, \text { or } \mathrm{SFE}>15 \mathrm{~g} / \text { day in run-in } \\
\text { phase), } \mathrm{CP}(\text { radiographically or } \\
\text { histologically proven) total or } \\
\text { partial pancreatectomy }>180 \text { days }\end{array}$ & NR & 14 & $\begin{array}{c}\text { PERT } 52 \\
\text { Placebo } 50.6\end{array}$ & $54(39 / 15)$ \\
\hline Thorat, 2012 & India & $\begin{array}{c}\text { June } 2008 \text { to } \\
\text { May } 2010\end{array}$ & $\begin{array}{l}\text { Multicenter, randomized, } \\
\text { double-blind, placebo- } \\
\text { controlled parallel }\end{array}$ & $\begin{array}{l}\geq 18 \mathrm{y}, \mathrm{EPI}(\mathrm{CFA}<80 \% \text { during the } \\
\text { run-in phase }), \mathrm{CP}(\text { radiographically } \\
\text { or histologically proven) }\end{array}$ & NR & 18 & $\begin{array}{c}\text { PERT } 42.6 \\
\text { Placebo } 43.2\end{array}$ & $62(47 / 15)$ \\
\hline Seiler, 2013 & Europe & NR & $\begin{array}{l}\text { Multicenter, Randomized, } \\
\text { double-blind, placebo- } \\
\text { controlled parallel }\end{array}$ & $\begin{array}{l}\geq 18 \mathrm{y} \text {, severe } \mathrm{EPI} \text { (baseline } \mathrm{CFA}< \\
80 \% \text { )due to partial or total } \mathrm{PR} \geq 6 \\
\text { months prior to study start, stable } \\
\text { condition after surgery (Karnofsky } \\
\text { index } \geq 70 \text { ) }\end{array}$ & $\begin{array}{c}\text { Pancreatic } \\
\text { surgery }\end{array}$ & 58 & $\begin{array}{c}\text { PERT } 57.6 \\
\text { Placebo } 59.3\end{array}$ & 58 \\
\hline
\end{tabular}

CP: chronic pancreatitis. CAP: chronic alcoholic pancreatitis PS: pancreatic surgery. A: alcoholic. I: idiopathic. O: obstructive. H: hyperlipidemic. EPI: exocrine pancreatic insufficiency. EPF: exocrine pancreatic function. R: reported. NR: not reported. CFA: coefficient of fat absorption. SFE: stool fat excretion. PERT: pancreatic enzyme replacement therapy.

Table 2: Jadad score of included studies

\begin{tabular}{llllll}
\hline Study & Randomization & Double-blind & $\begin{array}{l}\text { Withdrawals } \\
\text { and dropouts }\end{array}$ & $\begin{array}{l}\text { Allocation } \\
\text { concealment }\end{array}$ & Jadad score \\
\hline Halgreen, 1986 & 1 & 1 & 0 & 1 & 3 \\
Paris, 1993 & 1 & 1 & 1 & 0 & 3 \\
O'Keefe, 2001 & 1 & 0 & 1 & 0 & 2 \\
Safdi, 2006 & 1 & 1 & 1 & 0 & 3 \\
Whitcomb, 2010 & 1 & 2 & 1 & 1 & 5 \\
Thorat, 2012 & 1 & 2 & 1 & 1 & 5 \\
Seiler, 2013 & 1 & 2 & 1 & 1 & 5 \\
\hline
\end{tabular}

of chronic pancreatitis. Pancreatic surgery may be involved in benign or malignant factors, and the type or extension of surgery. Each original RCT included CP or PS patients with diverse etiologies, but did not stratify or observe the outcomes based on the etiology, which may be relevant to the heterogeneity and bias.

It is a pity that RCTs of cystic fibrosis patients, including adolescents, were excluded owing to our inclusion criteria of adult patients. Creon or pancrelipase has been indicated for effective and safe treatment of steatorrhea in adult and adolescent patients with exocrine pancreatic dysfunction due to cystic fibrosis [27, 28]. And a novel purified PERT, liprotamase has been demonstrated to enhance fat and nitrogen absorption without safety concerns in CF patients [29]. Though the effects of PERT are testified by some studies, more extensive and comprehensive original researches about PERT are required to develop on $\mathrm{CF}$ to ensure consistent quality, efficacy and safety.

All RCTs described the run-in or wash out phase before the double mind treatment period, in which $72 \mathrm{~h}$ stool collection and analysis were performed to ensure eligible steatorrhea patients. After the phase, candidates had the same baseline. In addition, all the RCTs recorded the $72 \mathrm{~h}$ stool collection in run-in and randomized phase and daily fat intake. However, original studies merely conducted around seven days' PERT before analyzing the outcomes without long-term treatment and follow-up to fat 
Table 3: Clinical trials on treatment of pancreatic exocrine insufficiency

\begin{tabular}{|c|c|c|c|c|c|c|c|c|c|c|}
\hline \multirow[t]{2}{*}{ Study } & \multirow[t]{2}{*}{ Run-in phase } & \multirow{2}{*}{$\begin{array}{l}\text { No of } \\
\text { PERT }\end{array}$} & \multirow{2}{*}{$\begin{array}{c}\text { No of } \\
\text { placebo }\end{array}$} & \multirow{2}{*}{$\begin{array}{l}\text { Fat intake/ } \\
\text { day }(g)\end{array}$} & \multicolumn{3}{|c|}{ Intervention } & \multirow{2}{*}{$\begin{array}{c}\text { Time of stool fat } \\
\text { collection }\end{array}$} & \multirow{2}{*}{$\begin{array}{c}\text { Mean change } \\
\text { of CFA (pert vs. } \\
\text { placebo) }\end{array}$} & \multirow{2}{*}{$\begin{array}{c}\text { Adverse } \\
\text { events }\end{array}$} \\
\hline & & & & & Type & Dosage(oral) & $\begin{array}{c}\text { Time } \\
\text { (days) }\end{array}$ & & & \\
\hline Halgreen, 1986 & 14 days & 11 & 11 & 100 & $\begin{array}{l}\text { Pancreaze }^{18} \text { EC, MS (L: } \\
4000 \text { NFU A: } 20,000 \\
\text { NFU, P: } 25,000 \text { NFU) }\end{array}$ & $\begin{array}{l}\text { Meal: } 2 \text { capsules, } \\
\text { tid. snack: } 1 \text { bid. }\end{array}$ & 14 & $\begin{array}{l}\text { 2-day equilibration } \\
\text { followed by } 3 \text {-day } \\
\text { collection }\end{array}$ & NR & NR \\
\hline $\begin{array}{c}\text { Paris, } \\
1993\end{array}$ & 7-9 days & 32 & 28 & $\geq 100$ & $\begin{array}{l}\text { Panzytrat }{ }^{\circledR 8} 25000 \text { EC, } \\
\text { MT (L: } 25000, \text { A: } 22500, \\
\text { P: } 1250) \text { Ph. Eur }\end{array}$ & $\begin{array}{l}\text { meal:2capsules } \\
\text { tid. }\end{array}$ & 7 & $\begin{array}{l}\text { 4-day equilibration } \\
\text { followed by 3-day } \\
\text { collection }\end{array}$ & 23.7 vs. 19.7 & $\begin{array}{l}\text { PERT: } 12.5 \% \\
\text { Placebo: } 10.7 \%\end{array}$ \\
\hline $\begin{array}{l}\text { O'Keefe, } \\
2001\end{array}$ & $\begin{array}{c}\text { 7-day placebo } \\
\text { followed by 7-day } \\
\text { PERT }\end{array}$ & 15 & 14 & 100 & $\begin{array}{c}\text { Pancreatic enzyme } \\
\text { supplement, EC, MMS } \\
\text { (L: 10,000 USP U A: } \\
33,200 \text { USP U, P: } 37,500 \\
\text { USP U) }\end{array}$ & $\begin{array}{l}\text { Meal: } 4 \text { capsules } \\
\text { tid. snack: } 2 \text { bid. }\end{array}$ & 14 & $\begin{array}{l}\text { 4-day equilibration } \\
\text { followed by 3-day } \\
\text { collection in placebo } \\
\text { period, 11-day } \\
\text { equilibration followed by } \\
\text { 3-day collection in PERT } \\
\text { period }\end{array}$ & $\begin{array}{l}26.8 \text { vs. } 0 \\
P=0.002\end{array}$ & NR \\
\hline $\begin{array}{l}\text { Safdi, } \\
2006\end{array}$ & 14- day placebo & 13 & 14 & $\geq 100$ & $\begin{array}{l}\text { Creon } 10 \text { EC, delayed- } \\
\text { release MMS (L: } 10000 \\
\text { USP U, P: } 37500 \text { USP U, } \\
\text { A: } 33200 \text { USP U) }\end{array}$ & $\begin{array}{l}\text { Meal: } 4 \text { capsules } \\
\text { tid. snack: } 2 \\
\text { capsules bid. }\end{array}$ & 14 & $\begin{array}{l}\text { 11-day equilibration } \\
\text { followed by 3-day } \\
\text { collection }\end{array}$ & $\begin{array}{c}36.7 \text { vs. } 12.1 \\
P=0.0185\end{array}$ & $\begin{array}{l}\text { PERT: } 35.7 \% \text {, } \\
\text { Placebo: } 23.1 \%\end{array}$ \\
\hline $\begin{array}{l}\text { Whitcomb, } \\
2010\end{array}$ & 5-day placebo & 25 & 29 & $\geq 100$ & $\begin{array}{c}\text { Creon } \\
\text { (pancrelipase) } 12,000 \\
\text { MMS USP U }\end{array}$ & $\begin{array}{l}\text { Meal: } 6 \text { capsules } \\
\text { tid. snack:3 } \\
\text { capsules bid. }\end{array}$ & 7 & $\begin{array}{l}\text { 2-day equilibration } \\
\text { followed by } 3 \text {-day } \\
\text { collection in run-in phase }\end{array}$ & $\begin{array}{c}32.1 \text { vs. } 8.8 \\
P<0.0001\end{array}$ & $\begin{array}{l}\text { PERT: } 20.0 \% \text {, } \\
\text { Placebo: } 20.7 \%\end{array}$ \\
\hline $\begin{array}{l}\text { Thorat, } \\
2012\end{array}$ & $\begin{array}{l}\text { 7-day followed by } \\
\text { 7-day PERT }\end{array}$ & 34 & 28 & $\geq 100$ & $\begin{array}{c}\text { Creon } 40000 \text { MMS } \\
\text { Ph. Eur }\end{array}$ & $\begin{array}{l}\text { Meal: } 2 \text { capsules } \\
\text { tid. snack: } 1 \text { bid. }\end{array}$ & 7 & $\begin{array}{c}\text { 4-day equilibration } \\
\text { followed by 3-day } \\
\text { collection }\end{array}$ & $\begin{array}{c}18.5 \text { vs. } 4.1 \\
P=0.001\end{array}$ & $\begin{array}{l}\text { PERT: } 35.3 \%, \\
\text { Placebo: } \\
25.0 \%\end{array}$ \\
\hline $\begin{array}{l}\text { Seiler, } \\
2013\end{array}$ & $\begin{array}{l}\text { 7-day followed by } \\
\text { 7-day PERT }\end{array}$ & 32 & 26 & $\begin{array}{l}\text { Reported, } \\
\text { not given }\end{array}$ & $\begin{array}{c}\text { Creon } 25000 \text { MMS } \\
\text { Ph. Eur }\end{array}$ & $\begin{array}{c}\text { Meal: } 3 \text { capsules } \\
\text { tid. } \\
\text { Snack: } 2 \text { bid. }\end{array}$ & 7 & $\begin{array}{l}\text { 4-day equilibration } \\
\text { followed by } \\
\text { 3-day collection }\end{array}$ & $\begin{array}{c}21.4 \text { vs. }-4.2 \\
P<0.001\end{array}$ & $\begin{array}{c}\text { PERT: } 37.5 \% \\
\text { Placebo: } 26.9 \%\end{array}$ \\
\hline
\end{tabular}

PERT: pancreatic enzyme replacement therapy. EC: enteric-coated MS: microspheres. MT: microtablet. L: lipase. A: amylase. P: protease. MMS: minimicrospheres. FA: fat absorption. SFE: Stool fat excretion. CFA: coefficient of fat absorption. NR: not reported. NFU: national formulary units. IU: international unit. USP U: United States Pharmacopeia units. Ph. Eur: European pharmacopoeia.

$(1 \mathrm{USP}=1 \mathrm{Ph}$. Eur. $=1 \mathrm{NFU})$

absorption and weight gain, though two studies developed 1-year open-label extensions and obtained increased body weight and BMI $[22,30]$. The coefficient of fat absorption, used as the primary results though, in fact is inconvenient for an indirect clinical sign. The recommendation for the enteral nutrition after PERT of the European guidelines indicates the markers of treatment success as the weight gain or improvement of the steatorrhea [31]. Actually, weight gain need a long-time follow up and is a blunt way to assess the subtle and sensitive sign of nutrition [32]. Therefore, more high- evidenced RCTs about long term efficacy and safety of PERT are required.

Regrettably all RCTs included failed to attach importance to pancreatic diabetes, a complication of EPI. Pancreatic diabetes, also named type $3 \mathrm{c}$ diabetes, is distinguished from type 1 and 2 diabetes and causes endocrine dysfunction [33]. Pancreatic diabetes accounts for 1-2\% of all types of diabetes in North America, [34] $0.8 \%$ in a Japan nationwide study, [35] and $15-20 \%$ in India and Southeast Asia for endemic fibrocalcific or tropical pancreatitis [36-38], in fact has higher incidence than generally known due to underdiagnosis and misdiagnosis. Pancreatic diabetes usually manifests as "brittle diabetes" with poor glucose control due to impaired insulin, glucagon and pancreatic polypeptide. The symptoms of hyperglycemia and hypoglycemia are common. Unfortunately, there is no high evidence RCTs or recommendations for the treatment of type $3 \mathrm{c}$ diabetes, hence whose treatment refers to type 2 diabetes. The injection of insulin for hyperglycemia should be cautious in case of hypoglycemia on account of decreased hepatic insulin sensitivity, enhanced peripheral insulin sensitivity and subsequently decreased secretion of glucagon [39]. However, the study showed hypoglycemia is particularly tough to manage. PERT may exacerbate glucose mechanism for the effect of increasing glucose absorption, but on the other hand, decrease the incidence of hypoglycemia [1]. Chronic pancreatitis and diabetes are regarded as the risk factors of pancreatic malignancy. Metformin, due to low incidence of hypoglycemia and anti-neoplasm effects, is hence recommended as the first line therapy for pancreatic diabetes [40, 41].

The use of oral exogenous pancreatic enzyme was not standardized, only Creon ${ }^{\circledR}$ and Pancrease ${ }^{\circledR}$ in the included studies are approved by FDA.26 There exists a large possibility that different types of PERT possess various properties and potencies: lipase concentration, formulation, oral time and so on. Lipase contents maintain the primary therapeutic effect of PERT. A variety of lipase doses, within the recommended dose ranges from reviews, are applied by different studies according to the preexisting diseases due to the lack of formalized PERT dose guidelines. High dose may improve more steatorrhea and abdominal pain in cystic fibrosis patients with no different side effects [42]. Higher dose than usually used might obtain more fat and nitrogen absorption, and consequently 
improve nutritional parameters in more severe $\mathrm{CP}$ patients $[43,44]$. However, high strength PERT is demonstrated unimproved evident effectiveness but high expense and more adverse events, such as fibrosing colonopathy, hyperuricemia or potential for viral transmission [45-50]. Therefore, Cystic Fibrosis Consensus Committee provides a guideline that the upper limit of daily dosage of PERT in patients with cystic fibrosis: 10,000 IU lipase per $\mathrm{kg}$ body weight [51]. Moreover microspheres, with several millimeters in diameter, have lower risks of pyloric retention and diverse more rapidly, meanwhile decrease more steatorrhea and abdominal pain compared with tablets $[12,52]$. However, minimicrospheres are not superior to microspheres in treatment of EPI conversely higher cost, but on the other hand because of smaller size enhance patient compliance [53]. The time of oral PERT is administrated differently in studies, but is recommended to take in enzymes during meals at least after meals for optimal effect [54]. Whereas, original researches included failed to record the time of PERT intake. Due to impaired pancreatic bicarbonate secretion and relatively high gastric acid secretion, fat malabsorption in some studies still persists in patents with EPI during the treatment of enteric-coated enzyme microspheres alone. However, addition of proton pump inhibitors with optimal dose of PERT, fat digestion and residual steatorrhea can be significantly improved
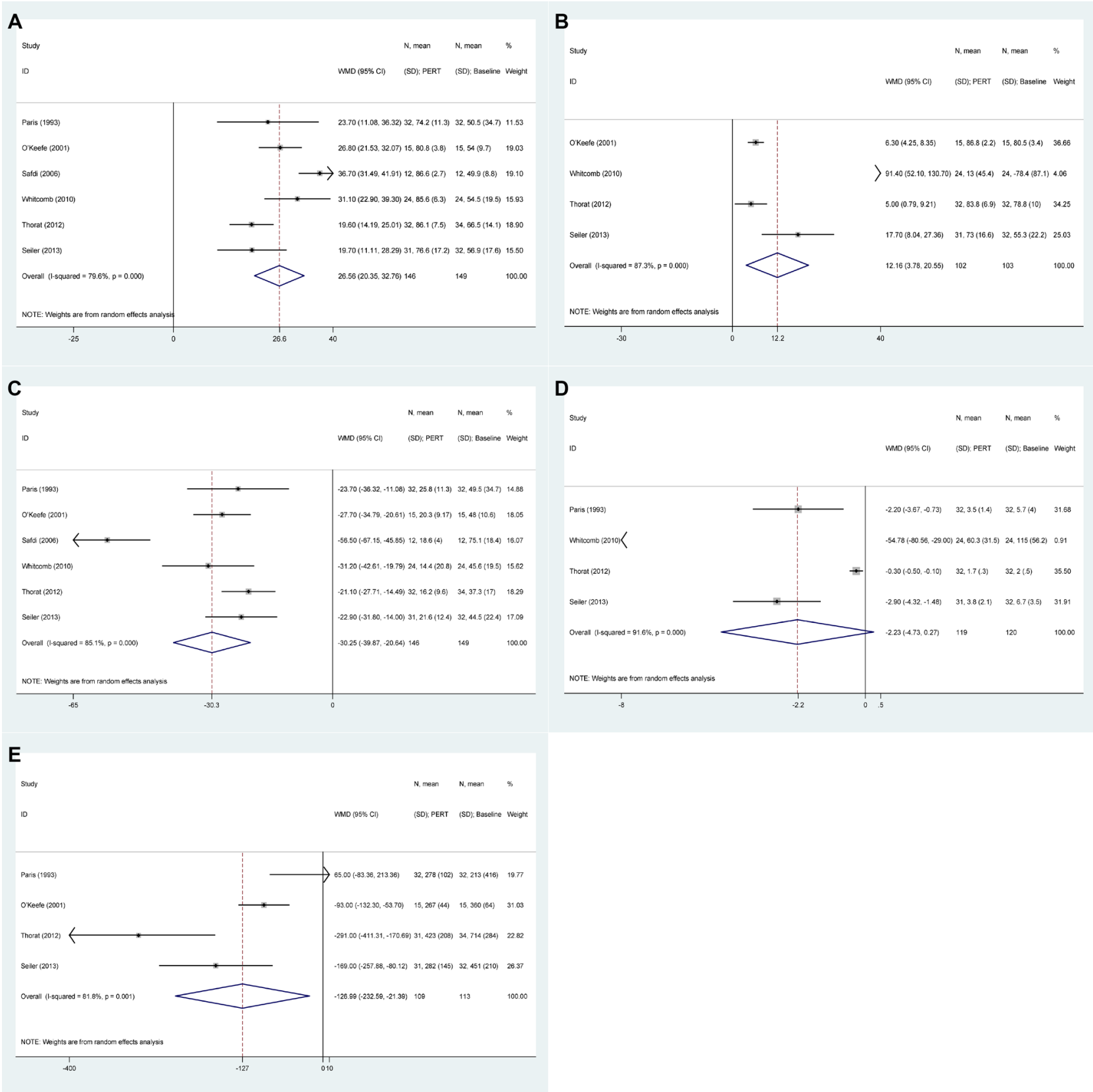

Figure 2: The pooled results of pancreatic enzyme replacement therapy versus baseline. (A) Coefficient of fat absorption (CFA). (B) Coefficient of nitrogen absorption (CNA). (C): Stool fat excretion (SFE). (D): Stool nitrogen excretion (SNE). (E): Stool weight (SW). 
or normalized in $\mathrm{CP}$ and $\mathrm{CF}$ patients to enhance the efficacy of PERT $[55,56]$. Meanwhile, in patients after pancreatic surgery, the prevalence of peptic ulcer is about $5 \%$, thus optimized therapy should be the combination of PPI and PERT [57]. Delayed gastric emptying, an early complication of post operation, is up to $40 \%$ in patients after Whipple's surgery, and usually treated with prokinetic drugs. Fibrates or Statins are used to lower hyperlipidemia [58].

Unfortunately, though diverse PERT may perform different therapeutic effects by grouping the forms of

\section{A}

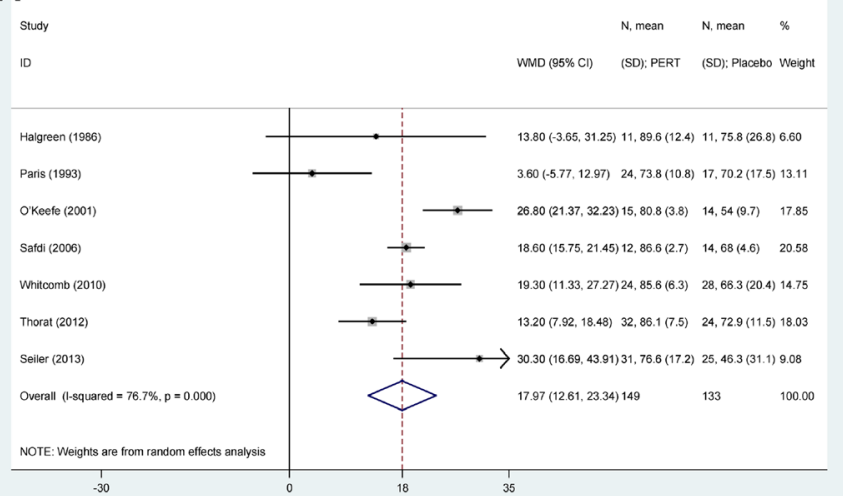

C

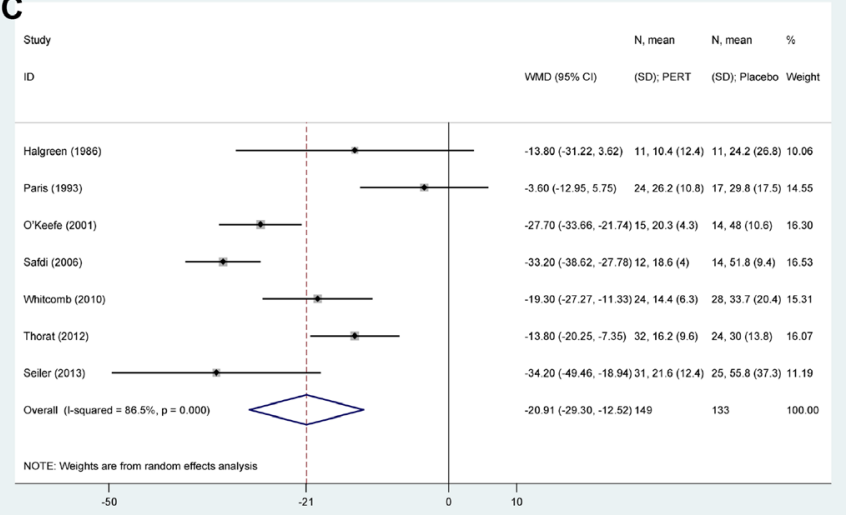

E

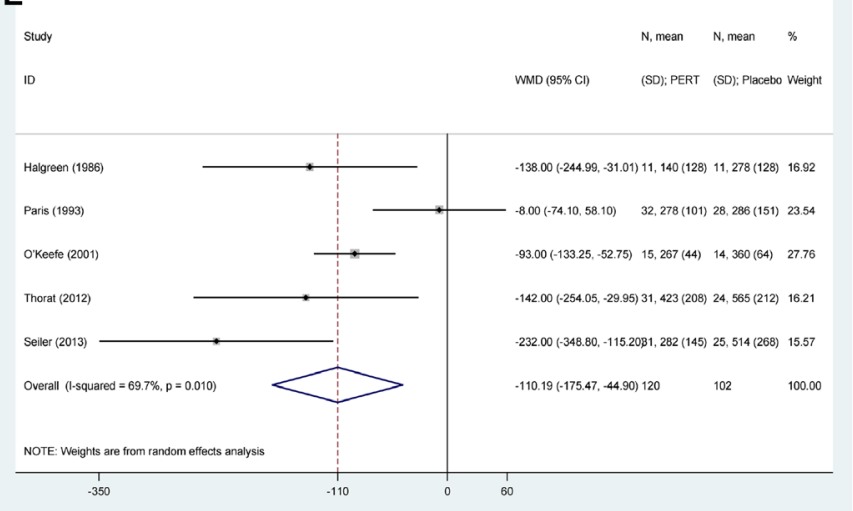

PERT in this meta-analysis, we are unable to stratify and observe PERT in depth for unknown property and potency of nonstandard treatments, we also cannot use meta regression analysis to further explore the origin of heterogeneity owing to small numbers of RCTs. However, the strength of the analysis includes complete assessments of efficacy and safety of PERT at the same time the methodological quality of original studies. Though a meta-analysis by de la Iglesia-Garcia D also concludes the efficacy of PERT, fails to consider the influence of standard PERT on EPI [14]. However, in our

B

Study

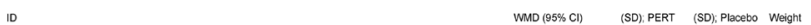

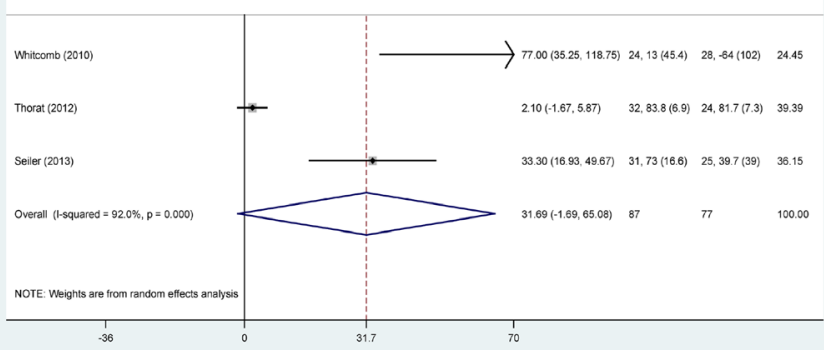

D
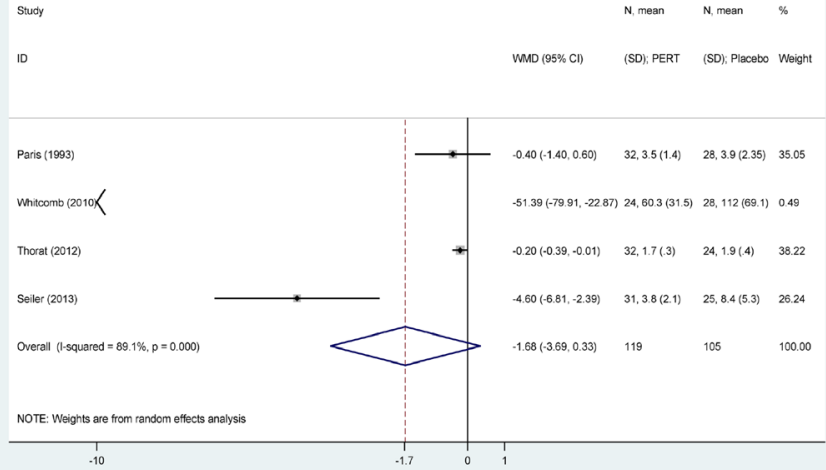

$\mathbf{F}$

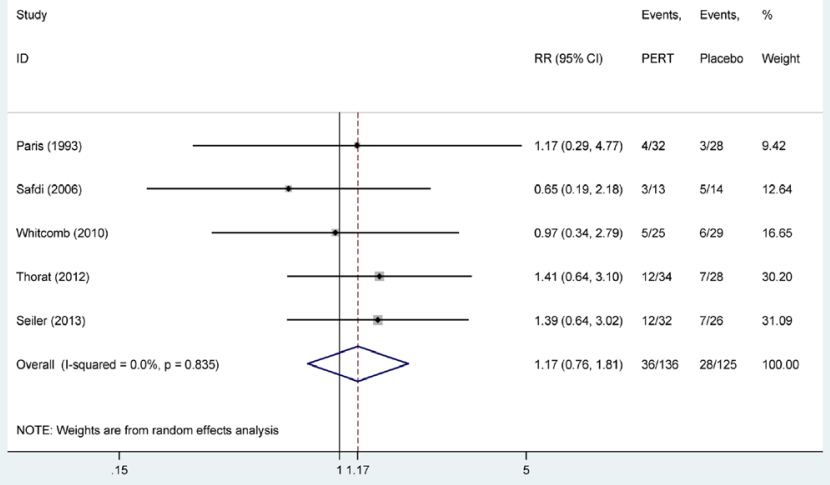

Figure 3: The pooled results of pancreatic enzyme replacement therapy versus placebo. (A) Coefficient of fat absorption (CFA). (B) Coefficient of nitrogen absorption (CNA). (C) Stool fat excretion (SFE). (D) Stool nitrogen excretion (SNE). (E) Stool weight (SW). (F) Adverse events (AE). 
Table 4: Subgroup analysis of the form of PERT and the sample size

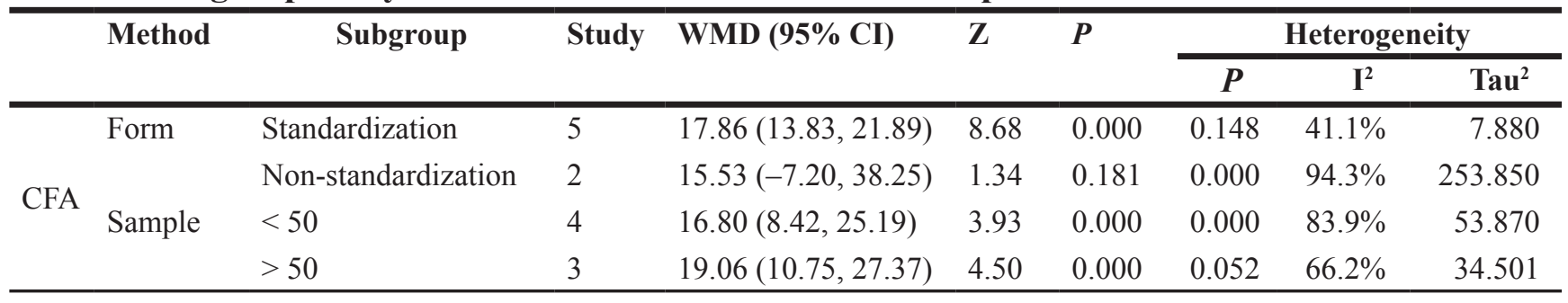

meta-analysis, we find out standard treatment with more improved physical parameters, thereby consider standard administration of PERT as a factor associated with the therapeutic effect, which may support a novel insight for treatment meanwhile as a basis for the exogeneous pancreatic enzymes selection.

In summary, our meta-analysis indicates that pancreatic enzyme replacement therapy has beneficial effects and tolerance in patients with exocrine pancreatic insufficiency, and standard forms of PERT may be more effective, by quantitatively observing seven RCTs. Although the high risk of bias cannot be completely found out and ruled out, to some degree the outcomes may be regarded as a basis of the current evidence for patients and physicians. Above all, more pancreatic enzyme replacement therapies are required to be normalized, and more large size and high quality comprehensive researches should be conducted to better evaluate the long-term effect of pancreatic enzyme replacement therapy on exocrine pancreatic insufficiency.

\section{MATERIALS AND METHODS}

\section{Search strategy}

A literature search of related studies was conducted in the databases of Pubmed, Medline, Cochrane library, Evidencebased medicine/clinical trials published before December 2016, using the following key words: pancreatic enzyme replacement therapy, pancreatic exocrine supplement, pancreatic lipase, Pancreatin, Ultrase, Cotazym, Creon, rotilase, amylase, exocrine pancreatic insufficiency/dysfunction, chronic pancreatitis, cystic fibrosis, pancreatic resection/surgery, pancreatic cancer/tumor/ neoplasm, alcohol, randomized controlled trials, placebocontrolled and RCTs. To ensure all relevant citations were included in this study, the reference lists from relevant articles

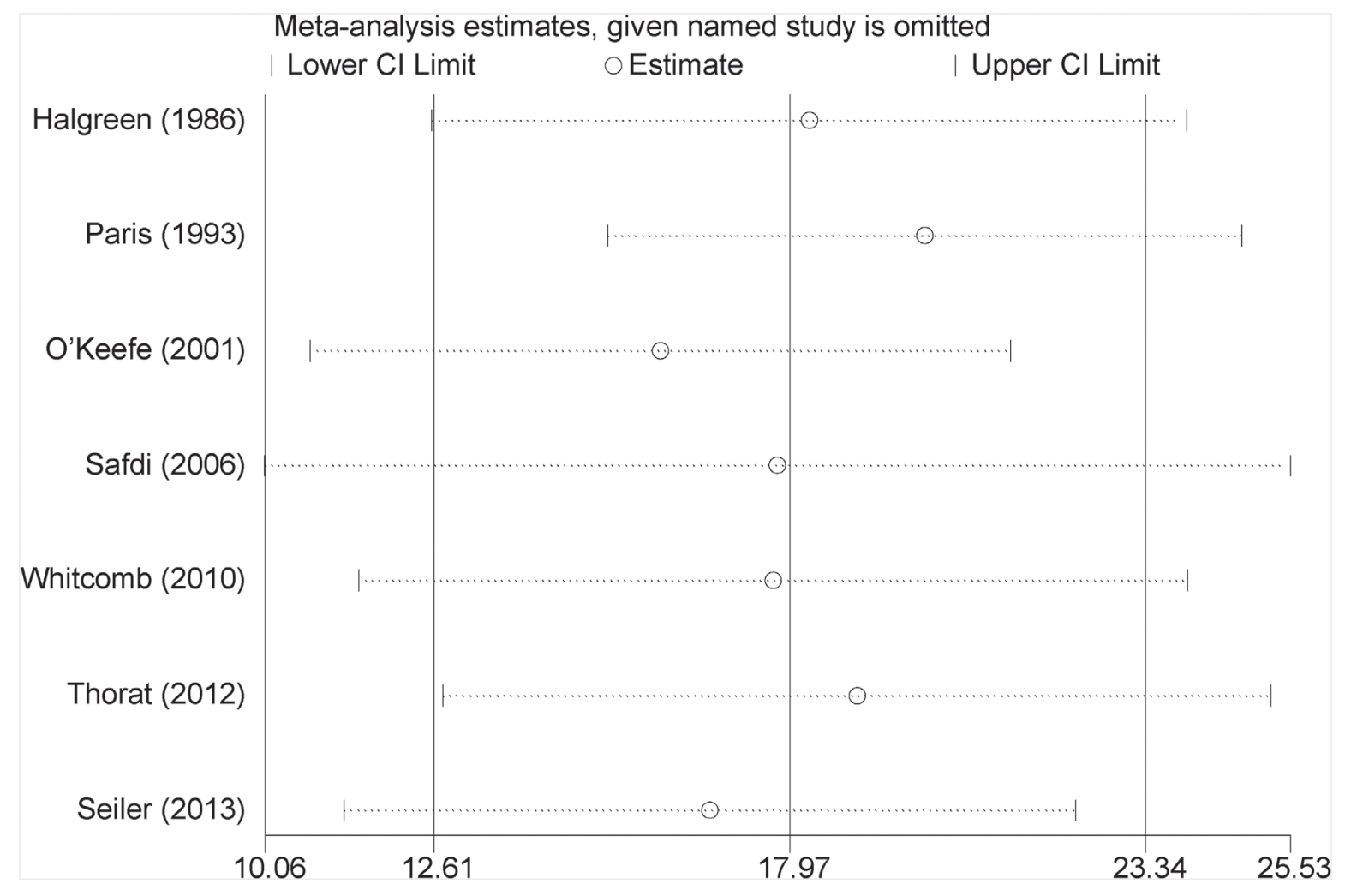

Figure 4: Leave-one -out analysis of pooled results of CFA between PERT and placebo group. Meta-analysis randomeffects estimates were used. The two ends of the dotted lines represented the $95 \% \mathrm{CI}$. 
were manually screened. The studies were limited to clinical trials and those written in the English language.

\section{Selection criteria}

To be included in this meta-analysis, studies had to meet the following criteria: (1) study: prospective, randomized, placebo-controlled studies; (2) patients: $\geq 18$ years old with confirmed EPI whatever etiology (chronic pancreatitis, cystic fibrosis, total or partial pancreatic resection et al); (3) intervention: oral PERT and placebo; (4) outcomes: the primary outcome: CFA, the secondary outcomes: CNA, SFE, SNE, SW, AE. Animal studies, abstracts, case reports, letters, expert opinions, editorials, reviews, meta-analyses, non-RCTs and duplicate studies were excluded.

\section{Data extraction and quality assessment}

Relevant data, including the first author's name, publication year, study design, quality score, number of patients, diagnosed criteria of EPI and CP, number of post pancreatic surgery or cystic fibrosis, the dosage and type of pancreatic enzyme, outcomes and adverse events were extracted by two reviewers. And each included study was assessed according to The Jadad score [59]. The criteria of this score was as follows: (1) randomization (yes $=1$ point, no $=0) ;(2)$ double-blind (described $=2$ points, mentioned but not described $=1$ point, no $=0$ ); (3) withdrawals and dropouts (yes $=1$ point, no $=0$ ); (4) allocation concealment (described $=1$ point, no $=0$ ). The quality score ranges from 0 to 5 points; a low-quality report score is $\leq 2$ and a high-quality report score is at least 3 .

\section{Outcomes assessed}

The primary outcome was the coefficient of fat absorption (CFA), using fat intake (100 g/day) and excretion (72 hours stool collection) to calculate out according to the following equation: CFA $(100 \%)=[($ fat intake in $\mathrm{g}$-fat excretion in $\mathrm{g}$ )/fat intake in $\mathrm{g}] \times 100$. The secondary outcomes contain CNA, stool fat excretion (SFE), stool nitrogen excretion (SNE), and stool weight (SW), stool consistency (formed/normal or soft/watery), stool frequency (stools per day), flatulence(none/mild/ moderate/severe), abdominal pain (none/mild/moderate/ severe) and adverse events. The CNA was calculated according to the following equation: CNA (100\%) = [(nitrogen intake in g-nitrogen excretion in $\mathrm{g}) /$ nitrogen intake in $\mathrm{g}] \times 100$.

\section{Statistical analysis}

Means and SDs of continuous variable were extracted from the forest plots using Stata MP 13 software (Cochrane Collaboration, Oxford, UK). Continuous variables were expressed as weighted mean differences (WMD) and discontinuous variables as RRs with 95\% CIs. Statistical heterogeneity is calculated by $\mathrm{I}^{2}$ statistic, with value over $50 \%$ indicating substantial heterogeneity and $P<0.1$ meaning significantly [60]. The randomeffects model was adopted for the heterogeneity. Subgroup analyses stratified by potential confounding factors was carried out to explore the sources of heterogeneity. In addition, sensitivity analysis was performed by removing one study each time and examining the influence of a specific study on the pooled results [61].

\section{Abbreviations}

PERT: pancreatic, enzyme, replacement therapy; EPI: exocrine, pancreatic, insufficiency; RCTs: randomized controlled trials; $\mathrm{CP}$ : chronic pancreatitis; $\mathrm{CF}$ : cystic fibrosis; PS: pancreatic surgery; CFA: coefficient of fat absorption; CNA: coefficient of nitrogen absorption; SFE: stool fat excretion; SNE: stool nitrogen excretion; SW: stool weight; AE: adverse events; SDs: standard deviations; WMD: weighted mean differences; RR: relative risk; 95\% CI: 95\% Confidence Interval

\section{Author contributions}

Study design, literature research and manuscript editing: Can Gan and Yan-Hua Chen; data acquisition and statistical analysis: Jin-Hang Gao and Huan Tong; reversion: Ling Liu; manuscript final version approval: Cheng-Wei Tang and Rui Liu

\section{ACKNOWLEDGMENTS}

We are indebted to no one for assistance with the manuscript.

\section{CONFLICTS OF INTEREST}

The authors have declared that no competing interests exist.

\section{FUNDING}

We did not receive any financial support.

\section{REFERENCES}

1. Kahl S, Malfertheiner P. Exocrine and endocrine pancreatic insufficiency after pancreatic surgery. Best practice \& research Clinical gastroenterology. 2004; 18:947-55.

2. Keller J, Layer P. Human pancreatic exocrine response to nutrients in health and disease. Gut. 2005; 54:vi1-28.

3. DiMagno EP, Go VL, Summerskill WH. Relations between pancreatic enzyme outputs and malabsorption in severe 
pancreatic insufficiency. The New England journal of medicine. 1973 ; 288:813-5.

4. Stevens T, Conwell DL, Zuccaro G Jr, Van Lente F, Lopez R, Purich E, Fein S. A prospective crossover study comparing secretin-stimulated endoscopic and Dreiling tube pancreatic function testing in patients evaluated for chronic pancreatitis. Gastrointest Endosc. 2008; 67:458-66.

5. Schneider AR, Hammerstingl R, Heller M, Povse N, Murzynski L, Vogl TJ, Caspary WF, Stein J. Does secretin-stimulated MRCP predict exocrine pancreatic insufficiency?: A comparison with noninvasive exocrine pancreatic function tests. J Clin Gastroenterol. 2006; 40:851-5.

6. Takacs T, Czako L, Dubravesik Z, Farkas G, Hegyi P, Hritz I, Kelemen D, Lasztity N, Morvay Z, Olah A, Pap A, Parniczky A, Patai A, et al. [Chronic pancreatitis. Evidence based management guidelines of the Hungarian Pancreatic Study Group]. Orv Hetil. 2015; 156:262-88. [Article in Hungarian].

7. Moran CE, Sosa EG, Martinez SM, Geldern P, Messina D, Russo A, Boerr L, Bai JC. Bone mineral density in patients with pancreatic insufficiency and steatorrhea. Am J Gastroenterol. 1997; 92:867-71.

8. Marotta F, Labadarios D, Frazer L, Girdwood A, Marks IN. Fat-soluble vitamin concentration in chronic alcoholinduced pancreatitis. Relationship with steatorrhea. Digestive diseases and sciences. 1994; 39:993-8.

9. Kuhn RJ, Gelrud A, Munck A, Caras S. CREON (Pancrelipase Delayed-Release Capsules) for the treatment of exocrine pancreatic insufficiency. Advances in therapy. 2010; 27:895-916.

10. Lévy $\mathrm{P}$, Domínguez-Muñoz E, Imrie $\mathrm{C}$, Löhr $\mathrm{M}$, Maisonneuve P. Epidemiology of chronic pancreatitis: burden of the disease and consequences. United European Gastroenterology Journal. 2014; 2:345-54.

11. Graff GR, Maguiness K, McNamara J, Morton R, Boyd D, Beckmann K, Bennett D. Efficacy and tolerability of a new formulation of pancrelipase delayed-release capsules in children aged 7 to 11 years with exocrine pancreatic insufficiency and cystic fibrosis: a multicenter, randomized, double-blind, placebo-controlled, two-period crossover, superiority study. Clin Ther. 2010; 32:89-103.

12. Stead RJ, Skypala I, Hodson ME, Batten JC. Enteric coated microspheres of pancreatin in the treatment of cystic fibrosis: comparison with a standard enteric coated preparation. Thorax. 1987; 42:533-7.

13. Yaghoobi M, McNabb-Baltar J, Bijarchi R, Cotton PB. Pancreatic Enzyme Supplements Are Not Effective for Relieving Abdominal Pain in Patients with Chronic Pancreatitis: Meta-Analysis and Systematic Review of Randomized Controlled Trials. Canadian journal of gastroenterology \& hepatology. 2016; 2016:8541839.

14. de la Iglesia-Garcia D, Huang W, Szatmary P, Baston-Rey I, Gonzalez-Lopez J, Prada-Ramallal G, Mukherjee R, Nunes QM, Dominguez-Munoz JE, Sutton R, Group NPBRUPA.
Efficacy of pancreatic enzyme replacement therapy in chronic pancreatitis: systematic review and meta-analysis. Gut. 2017;66:1354-1355.

15. Waljee AK, Dimagno MJ, Wu BU, Schoenfeld PS, Conwell DL. Systematic review: pancreatic enzyme treatment of malabsorption associated with chronic pancreatitis. Alimentary pharmacology \& therapeutics. 2009; 29:235-46.

16. Taylor JR, Gardner TB, Waljee AK, Dimagno MJ, Schoenfeld PS. Systematic review: efficacy and safety of pancreatic enzyme supplements for exocrine pancreatic insufficiency. Alimentary pharmacology \& therapeutics. 2010; 31:57-72.

17. Shafiq N, Rana S, Bhasin D, Pandhi P, Srivastava P, Sehmby SS, Kumar R, Malhotra S. Pancreatic enzymes for chronic pancreatitis. Cochrane Database Syst Rev. 2009; Cd006302.

18. Somaraju UR, Solis-Moya A. Pancreatic enzyme replacement therapy for people with cystic fibrosis. The Cochrane database of systematic reviews. 2016; 11:Cd008227.

19. Safdi M, Bekal PK, Martin S, Saeed ZA, Burton F, Toskes PP. The effects of oral pancreatic enzymes (Creon 10 capsule) on steatorrhea: a multicenter, placebo-controlled, parallel group trial in subjects with chronic pancreatitis. Pancreas. 2006; 33:156-62.

20. Whitcomb DC, Lehman GA, Vasileva G, Malecka-Panas E, Gubergrits N, Shen Y, Sander-Struckmeier S, Caras S. Pancrelipase delayed-release capsules (CREON) for exocrine pancreatic insufficiency due to chronic pancreatitis or pancreatic surgery: A double-blind randomized trial. Am J Gastroenterol. 2010; 105:2276-86.

21. Thorat V, Reddy N, Bhatia S, Bapaye A, Rajkumar JS, Kini DD, Kalla MM, Ramesh H. Randomised clinical trial: the efficacy and safety of pancreatin enteric-coated minimicrospheres (Creon 40000 MMS) in patients with pancreatic exocrine insufficiency due to chronic pancreatitis--a double-blind, placebo-controlled study. Aliment Pharmacol Ther. 2012; 36:426-36.

22. Seiler CM, Izbicki J, Varga-Szabo L, Czako L, Fiok J, Sperti C, Lerch MM, Pezzilli R, Vasileva G, Pap A, Varga M, Friess H. Randomised clinical trial: a 1-week, doubleblind, placebo-controlled study of pancreatin $25000 \mathrm{Ph}$. Eur. minimicrospheres (Creon $25000 \mathrm{MMS}$ ) for pancreatic exocrine insufficiency after pancreatic surgery, with a 1-year open-label extension. Aliment Pharmacol Ther. 2013; 37:691-702.

23. Halgreen H, Pedersen NT, Worning H. Symptomatic effect of pancreatic enzyme therapy in patients with chronic pancreatitis. Scandinavian journal of gastroenterology. 1986; 21:104-8.

24. Paris JC. A multicentre double-blind placebo-controlled study of the effect of a pancreatic enzyme formulation (Panzytrat 25000) on impaired lipid digestion in adults with chronic pancreatitis. Drug Investigation. 1993; 5:229-37.

25. O'Keefe SJ, Cariem AK, Levy M. The exacerbation of pancreatic endocrine dysfunction by potent pancreatic 
exocrine supplements in patients with chronic pancreatitis. Journal of clinical gastroenterology. 2001; 32:319-23.

26. Updated Questions and Answers for Healthcare Professionals and the Public: Use an Approved Pancreatic Enzyme Product (PEP). In: Services US Department of Health and Human Services, Food and Drug Administration, editors. 2012.

27. Trapnell BC, Maguiness K, Graff GR, Boyd D, Beckmann K, Caras S. Efficacy and safety of Creon 24,000 in subjects with exocrine pancreatic insufficiency due to cystic fibrosis. Journal of cystic fibrosis. 2009; 8:370-7.

28. Stern RC, Eisenberg JD, Wagener JS, Ahrens R, Rock M, doPico G, Orenstein DM. A comparison of the efficacy and tolerance of pancrelipase and placebo in the treatment of steatorrhea in cystic fibrosis patients with clinical exocrine pancreatic insufficiency. Am J Gastroenterol. 2000; 95:1932-8.

29. Borowitz D, Stevens C, Brettman LR, Campion M, Chatfield B, Cipolli M. International phase III trial of liprotamase efficacy and safety in pancreatic-insufficient cystic fibrosis patients. Journal of cystic fibrosis. 2011; 10:443-52.

30. Ramesh H, Reddy N, Bhatia S, Rajkumar JS, Bapaye A, Kini D, Kalla M, Thorat V. A 51-week, open-label clinical trial in India to assess the efficacy and safety of pancreatin 40000 enteric-coated minimicrospheres in patients with pancreatic exocrine insufficiency due to chronic pancreatitis. Pancreatology. 2013; 13:133-9.

31. Meier R, Ockenga J, Pertkiewicz M, Pap A, Milinic N, Macfie J, Loser C, Keim V. ESPEN Guidelines on Enteral Nutrition: Pancreas. Clin Nutr. 2006; 25:275-84.

32. Windsor JA. Pancreatic enzyme replacement therapy in chronic pancreatitis: a long way to go. Gut. 2017; 66:1354-5.

33. American Diabetes Association. Standards of medical care in diabetes. Diabetes care. 2011;34(suppl 1):S11-S61.

34. Ganda O. Secondary forms of diabetes; in Kahn CR, Weir GC (eds): Joslin's Diabetes Mellitus. New York, Lea \& Febiger. 1994.

35. Ito T, Otsuki M, Igarashi H, Kihara Y, Kawabe K, Nakamura T, Fujimori N, Oono T, Takayanagi R, Shimosegawa T. Epidemiological study of pancreatic diabetes in Japan in 2005: a nationwide study. Pancreas. 2010; 39:829-35.

36. Hardt PD, Brendel MD, Kloer HU, Bretzel RG. Is pancreatic diabetes (type $3 \mathrm{c}$ diabetes) underdiagnosed and misdiagnosed? Diabetes care. 2008; 31(Suppl 2):S165-9.

37. Ewald N, Kaufmann C, Raspe A, Kloer HU, Bretzel RG, Hardt PD. Prevalence of diabetes mellitus secondary to pancreatic diseases (type 3c). Diabetes/metabolism research and reviews. 2012; 28:338-42.

38. Abu-Bakare A, Taylor R, Gill GV, Alberti KG. Tropical or malnutrition-related diabetes: a real syndrome? Lancet. 1986; 1:1135-8.

39. Slezak LA, Andersen DK. Pancreatic resection: effects on glucose metabolism. World journal of surgery. 2001; 25:452-60.
40. Cui Y, Andersen DK. Pancreatogenic diabetes: special considerations for management. Pancreatology. 2011; 11:279-94.

41. Sadeghi N, Abbruzzese JL, Yeung SC, Hassan M, Li D. Metformin use is associated with better survival of diabetic patients with pancreatic cancer. Clinical cancer research. 2012; 18:2905-12.

42. Konstan MW, Stern RC, Trout JR, Sherman JM, Eigen H, Wagener JS, Duggan C, Wohl ME, Colin P. Ultrase MT12 and Ultrase MT20 in the treatment of exocrine pancreatic insufficiency in cystic fibrosis: safety and efficacy. Aliment Pharmacol Ther. 2004; 20:1365-71.

43. DiMagno MJ, Dimagno EP. Chronic pancreatitis. Current opinion in gastroenterology. 2006; 22:487-97.

44. Layer P, Keller J, Lankisch PG. Pancreatic enzyme replacement therapy. Current gastroenterology reports. 2001; 3:101-8.

45. Opekun AR Jr, Sutton FM Jr, Graham DY. Lack of doseresponse with Pancrease MT for the treatment of exocrine pancreatic insufficiency in adults. Alimentary pharmacology \& therapeutics. 1997; 11:981-6.

46. Smyth RL, van Velzen D, Smyth AR, Lloyd DA, Heaf DP. Strictures of ascending colon in cystic fibrosis and highstrength pancreatic enzymes. Lancet. 1994; 343:85-6.

47. Bansi DS, Price A, Russell C, Sarner M. Fibrosing colonopathy in an adult owing to over use of pancreatic enzyme supplements. Gut. 2000; 46:283-5.

48. Brett AS, Mack EH. Fibrosing colonopathy in adults with cystic fibrosis. AJR American journal of roentgenology. 2008; 190:W73.

49. Stapleton FB, Kennedy J, Nousia-Arvanitakis S, Linshaw MA. Hyperuricosuria due to high-dose pancreatic extract therapy in cystic fibrosis. The New England journal of medicine. 1976; 295:246-8.

50. Pavio N, Renou C, Di Liberto G, Boutrouille A, Eloit M. Hepatitis E: a curious zoonosis. Frontiers in bioscience. 2008; 13:7172-83.

51. Borowitz DS, Grand RJ, Durie PR. Use of pancreatic enzyme supplements for patients with cystic fibrosis in the context of fibrosing colonopathy. Consensus Committee. The Journal of pediatrics. 1995; 127:681-4.

52. Vyas H, Matthew DJ, Milla PJ. A comparison of enteric coated microspheres with enteric coated tablet pancreatic enzyme preparations in cystic fibrosis. A controlled study. European journal of pediatrics. 1990; 149:241-3.

53. Patchell CJ, Desai M, Weller PH, Macdonald A, Smyth RL, Bush A, Gilbody JS, Duff SA. Creon 10,000 Minimicrospheres vs. Creon 8,000 microspheres--an open randomised crossover preference study. J Cyst Fibros. 2002; 1:287-91.

54. Dominguez-Munoz JE, Iglesias-Garcia J, Iglesias-Rey M, Figueiras A, Vilarino-Insua M. Effect of the administration schedule on the therapeutic efficacy of oral pancreatic enzyme supplements in patients with exocrine pancreatic 
insufficiency: a randomized, three-way crossover study. Alimentary pharmacology \& therapeutics. 2005; 21:9931000.

55. Proesmans M, De Boeck K. Omeprazole, a proton pump inhibitor, improves residual steatorrhoea in cystic fibrosis patients treated with high dose pancreatic enzymes. European journal of pediatrics. 2003; 162:760-3.

56. Dominguez-Munoz JE, Iglesias-Garcia J, Iglesias-Rey M, Vilarino-Insua M. Optimising the therapy of exocrine pancreatic insufficiency by the association of a proton pump inhibitor to enteric coated pancreatic extracts. Gut. 2006; 55:1056-7.

57. Grace PA, Pitt HA, Longmire WP. Pylorus preserving pancreatoduodenectomy: an overview. The British journal of surgery. $1990 ; 77: 968-74$.
58. Riediger H, Makowiec F, Schareck WD, Hopt UT, Adam U. Delayed gastric emptying after pylorus-preserving pancreatoduodenectomy is strongly related to other postoperative complications. Journal of gastrointestinal surgery. 2003; 7:758-65.

59. Jadad AR, Moore RA, Carroll D, Jenkinson C, Reynolds DJ, Gavaghan DJ, McQuay HJ. Assessing the quality of reports of randomized clinical trials: is blinding necessary? Control Clin Trials. 1996; 17:1-12.

60. DerSimonian R, Laird N. Meta-analysis in clinical trials. Controlled clinical trials. 1986; 7:177-88.

61. Egger M, Davey Smith G, Schneider M, Minder C. Bias in meta-analysis detected by a simple, graphical test. BMJ. 1997; 315:629-34. 